\title{
Quality Evaluation of Meat from Adult Male Mithun (Bos frontalis)
}

\author{
Lalchamliani $^{1 *}$, Geeta Chauhan ${ }^{2}$, Abhijit Mitra ${ }^{1}$, S.S. Hanah ${ }^{1}$ and J.K. Chamuah ${ }^{1}$
}

${ }^{1}$ ICAR-National Research Centre on Mithun, Medziphema, Dimapur, Nagaland, India-797106

${ }^{2}$ Division of Livestock Products Technology, Indian Veterinary Research Institute, Izatnagar, Bareilly, U.P-243122, India

*Corresponding author

\section{Keywords}

Mithun meat, Adult, Physicochemical properties, Proximate composition, Functional properties, Meat quality

\section{Article Info}

Accepted: 04 April 2019 Available Online: 10 May 2019

\section{A B S T R A C T}

The present study was conducted to study the physico-chemical and functional properties of mithun (Bos frontalis) meat. Mithun were reared under semi-intensive system at ICARNational Research Centre on mithun farm, Medziphema, Nagaland, India, located between $25^{\circ} 54^{\prime} 30^{\prime \prime}$ North latitude and $93^{\circ} 44^{\prime} 15^{\prime \prime}$ East longitude, at an altitude range from 250-300 m mean sea level. Male mithun (age 4-7 years) with good body condition (score 5-6) were selected from the mithun farm which were maintained under similar housing, feeding and other managemental conditions. Mithun meat was obtained from Longissimus dorsi muscle and the physico-chemical characteristics viz., $\mathrm{pH}$, myoglobin, salt soluble protein, water soluble protein; myofibrillar fragmentation index, muscle fibre diameter, shear force and nutritional composition viz., proximate composition, calorific value and functional properties like water holding capacity were studied and was also subjected for sensory evaluation. The ultimate $\mathrm{pH}$ of the meat was recorded to be $5.78 \pm 0.05$. Moisture, Protein, fat, ash content of adult male mithun meat was $73.66 \pm 0.35,23.87 \pm 0.86,0.66 \pm 0.10$, $1.07 \pm 0.04$ respectively. Physicochemical and functional properties of adult male mithun meat shows that mithun meat was dark red in colour having a desirable water holding capacity, myofibrillar fragmentation index, salt soluble and water soluble protein. Panellists gave higher scores for all the sensory attributes which shows that mithun meat is highly preferred and relished by the consumers.

\section{Introduction}

Meat is an excellent source of good quality animal protein which provides all the essential amino acids and various micronutrients in proper proportion to human being (National Health and Medical Research council, 2006). Consumers are now more focused on the quality and nutritional characteristics of foods including meat and meat products and they are increasingly focusing on their eating habits and nutrient intake as well as food safety (Garnier et al., 2003). Due to growing awareness, consumers have become more selective for meat, detailed knowledge on the composition of meat is necessary to understand its functional properties and its meat quality. The health and vitality issue can be solved by control over the criteria of importance characterizing meat 
wholesomeness and selection of the healthiest product, in that way improving body lipid balance (Watts et al., 1988). In North East states meat is the main source of animal protein, about $18 \%$ out of the total food expenditure is used in meat (Mahanjan et al., 2015) and meat consumption pattern and expenditure are 2-3 folds higher compared to the National average which underscores importance of meat in North-Eastern Hill Region (NEHR). Mithun (Bos frontalis) is a unique ruminant found in the hill regions of northeast India, Myanmar, Bhutan, Bangladesh, China and Malaysia. The Indian gaur (Bos gaurus); also known as the "Indian bison" and as the "gayal" is the wild ancestor of mithun (Rajkhowa et al., 2005). Chromosomally, gaur and mithun are identical (Gupta et al., 1999). Mithun (Bos frontalis), the gift of rich biodiversity, play an important role in their livelihood. This majestic animal has an important place in the social, cultural, religious and economic life of the tribal population especially of the states of Arunachal Pradesh, Nagaland, Manipur and Mizoram. Mithun meat is highly preferred and well relished as traditional delicacy among the tribal population of the north eastern region. This prized hill animal of the North-Eastern Hill Region (NEHR) is considered to be an efficient converter of forest biomass into valued meat with a daily body-weight gain of 324-497g (Heli et al., 1994). Mondal et al., (2004a) on studying the body confirmation traits of mithun reported that mithun had similarity with most of the meat or draught purpose European breeds of cattle and Indian buffaloes in respect of most of the type traits (Shrikhande et al., 1996). Mondal et al., (2004) on studying the growth rate and biometrical measurements in mithun calves under semi-intensive system recorded an average daily body weight gain of $480 \mathrm{~g}$ in male and $379 \mathrm{~g}$ in female mithun calves on fifth month of age under semi-intensive system. The birth weight of mithun calves varies from 17 to $20 \mathrm{~kg}$ (Mondal et al., 2001). It was also reported that male calves are heavier at birth than female (16 to $18 \mathrm{~kg}$ ). Mithun attains maturity at around 3 years of age with an adult body weight of 400 to 500 $\mathrm{kg}$.

ICMR has recommended that protein intake of male should be $60 \mathrm{gm} /$ day and that of female should be $50 \mathrm{gm} /$ day. There is a great demand for meat in the North East region of India. On other hand, North Eastern region is deficient in meat production and about $35 \%$ of the requirement of the region is met through imports from other states. Mithun meat is a delicacy of the ethnic tribal population and is considered superior as compared to the meat of any other species and is highly demanded by the people among the ethnic tribes and is regarded as a loftier meat over the meat of any other species. Despite vast contribution of mithun to the ethnic tribal population in the North eastern region, their potential for utility as a meat sector, its nutritional composition, functional properties and its meat quality is not completely exploited. Mithun meat is not regularly consumed as compared to other meat species and is sacrificed for meat only during festivals, ceremonies and only on special occasions. To the best of our knowledge, meagre study has been done regarding its physicochemical and functional properties. In order to develop mithun meat as a profitable venture and for aiming towards the future large-scale and extensive use of this species as meat animal, knowledge of its meat quality is important in order to create consumer sawareness and satisfaction.

\section{Materials and Methods}

Mihun meat sample was collected from longissimus dorsi muscle of the carcass immediately after exanguination from local municipal slaughterhouse, Dimapur, India. 
Mithun were slaughtered according to traditional halal method followed in India. Muscle was packed in (LDPE) bags, kept in the ice box filled with ice pack and was then transported to ICAR-NRC on Mithun L.P.T laboratory. It was kept at $4 \pm 1^{\circ} \mathrm{C}$ in a domestic refrigerator for about 24 hours for rigor mortis to complete so as to avoid cold shortening and excessive drip loss, later the separable fat and connective tissue was removed. The meat was then portioned, packed in LDPE bags (200 gauge) and was transferred to a freezer maintained at $-20 \pm 1^{\circ} \mathrm{C}$ until processed. The meat was thawed at $4 \pm 1{ }^{\circ} \mathrm{C}$ for $12 \mathrm{~h}$ before evaluation. The meat samples for quality assessment was ground in a mincer packed in PET (Polyethylene Teraphthalate) jars and was stored in refrigeration $\left(4 \pm 1{ }^{\circ} \mathrm{C}\right)$ until required. The samples were analysed for physicochemical, functional properties, total calorific values and for its sensory attributes.

\section{pH}

The $\mathrm{pH}$ of minced mithun meat was determined as per Trout et al., (1992). Homogenates were prepared by blending $10 \mathrm{~g}$ sample with $90 \mathrm{ml}$ distilled water using an Ultra Turrax tissue homogenizer (Model T25, Janke and Kenkel, 1 KA LaborTechnik, Germany) for $1 \mathrm{~min}$. The $\mathrm{pH}$ of the homogenates was recorded by immersing combined glass electrode of digital ph meter (Model CP 901, Century Instrument Ltd. Chandigarh).

\section{Myoglobin content}

Estimation of myoglobin content was done by modified procedure of Warris (1979). Ten grams of the meat sample was taken and was blended with cold $0.04 \mathrm{M}$ phosphate buffer at $\mathrm{pH} 6.8$ for 2 minutes in a homogenizer. The mixture was kept at $4^{\circ} \mathrm{C}$ for 1 hour and is then centrifuged at $5600 \mathrm{rpm}$ for 30 minutes. It was then filtered with Whatmann filter paper
No. 1 and the absorbance were measured at $525 \mathrm{~nm}$ and $700 \mathrm{~nm}$.

\section{Salt soluble protein}

The salt soluble protein content was determined by a slight modification of the method of Knipe et al., (1985). Finely minced $10 \mathrm{~g}$ meat sample was homogenized with chilled $25 \mathrm{ml} 0.6 \mathrm{M} \mathrm{NaCl}$ for $1 \mathrm{~min}$ in Ultra Turrax tissue homogenizer (Model T25, Janke and Kenkel, 1 KA Lab or Technik, Germany) at high speed and then added about $25 \mathrm{ml}$ chilled $0.6 \mathrm{NaCl}$ and homogenized for 1 minute. This homogenate was quantitatively transferred with two rinsings to $125 \mathrm{ml}$ polycarbonate centrifuge tubes and the final volume was made to $100 \mathrm{ml}$. The samples were stirred on a Cyclomixer (REMI equipments) for 2 minute and centrifuge at $5500 \mathrm{rpm}$ for 15 minutes in REMI research centrifuge. After centrifugation, the fat layer floating on the surface was gently moved to one side with a stainless steel spatula and $1 \mathrm{ml}$ aliquot in duplicate were drawn from the clear salt solubilised protein solution. To each $1 \mathrm{ml}$ solution, $5 \mathrm{ml}$ Biuret reagent (Gornall et al., 1949) was added. In blank, $1 \mathrm{ml} 0.9 \% \mathrm{NaCl}$ was taken with $5 \mathrm{ml}$ Biuret reagent. This mixture was stirred and allowed to stand for 15 minutes for optimum colour development. Optical density was determined with a spectrophotometer (Elico Scanning Mini SL 177) at $540 \mathrm{~nm}$ and converted by using bovine serum albumin (BSA) standard curve to $(\mathrm{mg})$ protein per $\mathrm{ml}$ solution $\mathrm{SSP}$ was expressed as g per $100 \mathrm{~g}$ meat (\%).

\section{Water soluble protein}

The water soluble protein was determined by biuret method by extracting the water soluble protein with water and was measured with spectrophotometer using Biuret reagent. Four gm of the meat sample was homogenized with $30 \mathrm{ml}$ of distilled water in Ultra Turrax tissue 
homogenizer (Model T25, Janke and Kenkel, 1 KA LaborTechnik, Germany) for 2 minutes and was kept at overnight at $4^{\circ} \mathrm{C}$. The slurry was then centrifuged in refrigerated state at $5000 \mathrm{rpm}$ for $5 \mathrm{mins}$ and the supernatant were collected. The residue was extracted with 10 $\mathrm{ml}$ of chilled distilled water and was centrifuged again for $5000 \mathrm{rpm}$ for 5 minutes. The supernatant were then pooled together and the volume was made up to $50 \mathrm{ml}$ with chilled distilled water. $1 \mathrm{ml}$ of the aliquot was taken in a test tube and $5 \mathrm{ml}$ of Biuret reagent was added to it. A blank was prepared by using $1 \mathrm{ml}$ of $0.9 \% \mathrm{NaCl}$ and $5 \mathrm{ml}$ of Biuret reagent. Both the test tubes were then incubated for 15 minutes for colour development. Optical density was determined with a spectrophotometer (Elico Scanning Mini SL 177) at $540 \mathrm{~nm}$ and converted by using bovine serum albumin (BSA) standard curve to $(\mathrm{mg})$ protein per ml solution WSP was expressed as g per $100 \mathrm{~g}$ meat (\%).

\section{Myofibrillar fragmentation index}

The myofibrillar fragmentation index (MFI) was determined in buffalo meat samples as described by Davis et al., (1980) with slight modifications. This basically measured the proportion of muscle fragments that passed through the muslin cloth after sample had been subjected to a high speed homogenisation treatment.

Ten grams minced meat samples were transferred to a $100 \mathrm{ml}$ polycarbonate centrifuge tube containing $50 \mathrm{ml}$ of cold 0.25 $\mathrm{M}$ sucrose and $0.02 \mathrm{M}$ potassium chloride solutions. The samples were allowed to equilibrate for $5 \mathrm{~min}$. Then the samples were homogenized for $40 \mathrm{~s}$ at full speed with an Ultra Turrax tissue homogenizer (Model T24, Janke and Kenkel, 1 KA LaborTechnik, Germany). The homogenate was filtered through a pre-weighed muslin cloth through a filtration unit fitted with a funnel placed in a
$50 \mathrm{ml}$ test tube. The homogenate was stirred with a glass rod to hasten filtration. A gentle and uniform squeezing was made to all the samples in the muslin cloth to drain out the excess moisture present. The resulting fraction of muscle fragments collected on the screen was bolted with Whatman No. 1 filter paper. The weight of the sample with the screen was taken after 40 minutes of drying at $37 \mathrm{C}$ in an incubator (Bharat Instrument \& Chemicals, New Delhi, India). MFI was calculated as a percentage of the weight of muscle fragments passed through (initial weight of muscle sample- weight of residue after drying) to that of the initial weight of the muscle sample.

\section{Muscle fibre diameter}

The fibre diameter of buffalo meat samples were assessed according to the method outlined by Jeremiah and Martin (1982). Five grams of the minced meat sample was homogenised in a Ultra Turrax tissue homogenizer (model T25, Janke and Kenkel, 1 KA LaborTechnik, Germany) at low speed for two $15 \mathrm{~s}$ periods inter-spaced with a $5 \mathrm{~s}$ resting interval in a $30 \mathrm{ml}$ solution containing $0.25 \mathrm{M}$ sucrose and $1 \mathrm{mM}$ EDTA (ethylene diamine tetra acetic acid) to produce a slurry. One drop of slurry was then transferred on to a glass slide and covered with a cover slip. The suspension was examined directly under a light microscope with 10X objective and $8 \mathrm{X}$ eyepiece equipped with calibrated micrometer. Muscle fibre diameter was measured as the mean diameter of the middle and the two extremities of the 25 randomly selected muscle fibres and expressed in micrometer.

\section{Cooking loss}

Cooking loss was determined by following the procedure described by (Honikel, 1998). Meat samples of approximately 100 gm were 
weighed and were sealed in plastic bags, it was then kept in water bath at $75^{\circ} \mathrm{C}$ for 50 mins followed by cooling, dry blotting and weighing. Cooking loss was calculated as follows:

Cooking loss \%=

Raw weight of the meat sample-Cooked weight of the meat sample

Raw weight of the meat sample

\section{Proximate composition}

The moisture, protein, fat and ash content of the mithun meat sample was estimated as per methods described by AOAC (2016).

\section{Calorific value}

Calories were calculated from the proximate analysis results using the following generalised equation:

K.cal $($ per $100 \mathrm{~g})=[(\%$ protein $)(4)]+[(\%$ fat $)$ $(9)]+[(\%$ carbohydrate $)(4)]$

\section{Shear force}

Warner-Bratzler shear force value was measured using Texture Analyser (Stable Micro Systems, Model TA-HD plus, Godalming, Surrey, UK).Chilled samples were equilibrated to room temperature before texture measurement.

The samples were cut into $15 \mathrm{~mm}$ diameter size. The cores were sheared with a Warner Bratzler blade attached to the texture analyzer perpendicular to the muscle fibre orientation with $50 \mathrm{~N}$ load range and a cross head speed set at $200 \mathrm{~mm} / \mathrm{min}$. Maximum force required to cut the samples (shear force) was recorded. The average values for each samples was recorded as the mean of duplicates and expressed in Newtons $(\mathrm{N})$.

\section{Physicochemical properties}

\section{Water holding capacity (WHC)}

Water holding capacity was determined according to Wardlaw et al., (1973) with slight modification. To $15 \mathrm{~g}$ finely minced meat sample in a $50 \mathrm{ml}$ polycarbonate centrifuge bottle, $22.5 \mathrm{ml}$ of $0.6 \mathrm{M} \mathrm{NaCl}$ was added, mixed with a glass rod, and stirred for 2 minutes on a Cyclomixer (REMI equipments). After holding for 15 minutes at $4 \mathrm{C}$ in order to allow the effect of $0.6 \mathrm{M} \mathrm{NaCl}$ to reach equilibrium, the meat slurry was again stirred for 1 minute on a Cyclomixer and immediately.

\section{Evaluation of sensory characteristics of mithun meat}

A six member panellists which comprise of staff of ICAR NRC on Mithun were trained according to guidelines for cookery and sensory analysis of meat and was briefed about the different sensory attributes. Sensory evaluation was done using 8 point descriptive scale (Keeton, 1983). The meat chunks $(3 \mathrm{~cm}$ cubes) were mixed with $1.5 \%$ salt and water (50\% of the meat taken) in a glass beaker $(250 \mathrm{ml})$ and covered with aluminium foil. Water in a pressure cooker was immerse up to one fourth of the height of the beaker.

The glass beakers containing meat sample were then placed in the pressure cooker. Cooking was done under high flame till the first whistle and then turn to cook under simmering for 30 minutes. The cooked samples were separated from the meat extract, were cooled to room temperature and was then subjected to sensory evaluation. Panellists were provided with filtered water to rinse their mouth between samples. Panellists evaluated samples for appearance, flavour, juiciness, tenderness and connective tissue residue using eight point scales where $8=$ 
excellent and 1= extremely poor. Panellists' scores were averaged for statistical analysis.

\section{Statistical analysis}

The experiments were repeated minimum of three times and the data generated for different quality characteristics were compiled and analyzed using SPSS (version 20.0 for windows; SPSS, Chicago, III., U.S.A.). The results were presented as means and pooled standard errors of the means.

\section{Results and Discussion}

\section{Physicochemical characteristics}

\section{pH}

The ultimate $\mathrm{pH}$ of mithun meat was observed to be $5.78 \pm 0.05$. The values are in consistent with the findings of Kiran et al., (2016) who reported a $\mathrm{pH}$ of 5.79 in old (above10 year's age) buffaloes and lower $\mathrm{pH}$ in old buffalo meat might be due to increased sensitivity to older animals to stress during slaughter which results in rapid breakdown of muscle glycogen. Kiran et al., (2015) reported a $\mathrm{pH}$ of $5.87 \pm 0.06$ and $5.70 \pm 0.03$ in longissimus lumborum (LL) and pso as major (PM) from buffalo of 10 years of age. Kandeepan et al., (2009) noted that normal values for $\mathrm{pHu}$ of buffalo meat ranges between 5.4 and 5.6. Out present findings indicates that $\mathrm{pHu}$ values of male mithun meat measured in the current study seem to be within the acceptable range.

\section{Myoglobin content}

In the present study the myoglobin content in adult male mithun was recorded to be $5.19 \pm 0.14(\mathrm{mg} / 100 \mathrm{gm})$. The concentration of myoglobin in the longissimus dorsi muscle of cattle in therange of 3-6 mg/g (Warris, 2000). Meat becomes darker and redder with increase in age, which is mainly due to increase in concentration of myoglobin pigment with age (Lawrie, 1991). The myoglobin content of adult mithun were slightly higher than other species, this indicates that mithun meat is darker than buffalo or beef (Table 1).

Babji et al., (1989) reported that myoblobin content of Malaysian beef Sirloin is 4.76 $\mathrm{mg} / \mathrm{g}$ and Malaysian buffalo sirloin is 4.92 $\mathrm{mg} / \mathrm{g}$ and that of Indian beef $4.86 \mathrm{mg} / \mathrm{g}$. Valin et al.(1984) opined that myoglobin content vary from 2.7 to $9.4 \mathrm{mg} / \mathrm{g}$ depending upon the type of muscle and age, meat becomes darker with increasing age and myoglobin concentration found to vary significantly $(\mathrm{P}<0.01)$ between old and young buffalo meat with 3.59 and $2.36 \mathrm{mg}$ myoglobin/g tissue, respectively.

\section{Salt soluble proteins}

Salt soluble protein content in adult male mithun was recorded to be $10.37 \pm 0.19$. Kandeepan et al., (2009) reported that spent male buffalo meat had salt soluble protein content of $6.04 \pm 0.09$. Spent female buffalo meat showed a SSP of $8.2 \%$ (Anjaneyulu et al., 1989). Myofibrillar protein concentration of $7.19 \%$ were recorded in male buffalo calf meat (Anjaneyulu et al., 1985).The percent SSP of buffalo thigh meat, tripe and heart were 6.30 and 4.40 and 4.53 respectively (Kondaiah et al., 1986).

\section{Water soluble proteins (\%)}

Water soluble proteins in adult mithun group were observed to be $6.86 \pm 0.39$. Supporting our results Kiran et al., (2016) reported a sarcoplasmic protein (\%) of $6.6 \%$ in old buffalo and $6.46 \%$ in young buffalo indicating higher sarcoplasmic protein content in meat from old buffaloes resulting in greater total protein extractability in old buffalo meat which influences protein functionality. 
Zarasvand et al., (2012) on studying the physico-chemical and functional properties and ultrastructure of ostrich meat and beef during aging reported that sarcoplasmic proteins (\%) of beef Longissimus dorsi muscle of 1.5 year of age of Swiss brown cattle has a $6.53 \pm 0.55 \%$ sarcoplasmic content and that of male ostrich (Iliofibularis muscle) of age 10-12 months has a $7.40 \pm 0.55 \%$..Sarcoplasmic concentration of $7.19 \%$ was recorded in male buffalo calf meat (Anjaneyulu et al., 1985). The percent water soluble protein of buffalo thigh meat, tripe and heart were $4.08,4.35 ; 2.87$ respectively (Kondaiah et al., 1986).

\section{Myofibrillar fragmentation index}

MFI of $76.98 \pm 0.90$ was recorded in the present study. MFI is a measure of myofibrillar protein degradation (Siedman et al., 1987). This was highly related to shear force and sensory tenderness ratings (Calkins and Davis, 1980). MFI was negatively correlated with the shear force value of buffalo meat. Myofibrillar fragmentation index (MFI) was reported to be 87.5 in 6year-old male Murrah buffaloes (Kulkarni et al., 1993). Kiranet al., (2016) reported MFI 73.05of old buffalo meat. MFI was highly and significantly related to sensory tenderness scores (Parrish et al., 1979).

\section{Muscle fibre diameter}

The muscle fibre diameter was observed to be $84.18 \pm 0.99 \mu \mathrm{m}$. Rao et al., (2009) and Nurainia et al., (2013) suggested that buffalo muscle fibre diameters are affected by age and not by gender. Li et al., (2018) also showed that muscle diameter increased significantly $(\mathrm{P}<0.05)$ with age. Our present study corroborates with the findings of Ilavarsan et al., (2016) who reported fibre diameter of $99.01 \pm 0.47 \mu \mathrm{m}$ in adult Toda buffaloes of age above 3 years. The muscle fibers are usually about $60-100 \mu \mathrm{m}$ in diameter (Warris, 2000). Muscle fiber diameter for fresh buffalo meat has been reported to be ranging from $35.32 \mathrm{~mm}$ (Anajneyulu et al., 1985), $60.76 \mathrm{~mm}$ (Naveena et al., 2004) and $41.72 \mathrm{~mm}$ (Naveena et al., 2011).

\section{Cooking loss}

Cooking loss $(\%)$ values of male mithun was recorded to be $34.62 \pm 0.99$. Cooking losses are negatively correlated with $\mathrm{pH}$ value (Purchas, 1990). Zarasv and et al., (2012) reported a cooking loss (\%) in beef longissimus dorsi muscle of age 1.5 year old male swiss brown cattle to be $34.68 \pm 0.0 .96$.

\section{Proximate composition}

Moisture, Protein, fat, Ash content of adult male mithun meat was $73.66 \pm 0.35$, $23.87 \pm 0.86, \quad 0.66 \pm 0.10, \quad 1.07 \pm 0.04$ respectively.

Li et al., (2018) reported that the moisture content of Binglangjang male buffalo (age 36 months) meat (longissimus dorsi) muscle $75.1 \%$. Moisture percentage of 74.04 to $77.75 \%$ has been reported for fresh buffalo meat (Anjaneyulu et al., 1985; Syed Ziauddin et al., 1994; Naveena et al., 2004). The protein content of mithun meat in the present study was higher than the previous workers who reported $17.90 \%$ crude protein content on fresh basis (Pal, 2000). Mondal et al., (2001) on studying the carcass characteristics of mithun reported that the crude protein (\%) in mithun muscle was 19.58 , ether extract $(\%)$ 0.42. Buffalo meat showed a protein percentage of 17.33 to $23.3 \%$ (Syed Ziauddin et al., 1994; Naveena et al., 2004).Kiran et al., (2016) reported higher $(\mathrm{P}>0.05)$ protein content in old buffalo meat $(21.87 \%)$ relative to meat from young buffaloes $(20.81 \%)$. Li et al., (2018) reported crude protein of $18.7 \pm 0.50$ to $22.5 \pm 0.61$ in Binglanjang male 
buffalo meat (Longissimus dorsi) of age upto 36 months. Among all the red meats, buffalo has been reported to have lowest concentration of total lipids $(1.37 \mathrm{~g} / 100 \mathrm{~g})$ and buffalo meat from 2 year old male calves showed a fat percentage of 1.0 to 3.5 (Kesava Rao and Kowale, 1991). Our present findings showed that mithun meat is much leaner than other animal species and the relatively low fat content in mithun meat is attributed to poor marbling. Lapitan et al., (2008) reported that ash content of crossbred cattle and buffalo consist of $1 \pm 0.05$ and $1.02 \pm 0.05$ respectively. Aziz et al., (2012) reported that ash content of buffalo above 2 years varies between 1.03 to $1.40 \%$ while in that of cattle above 2 years 1.13 to $1.46 \%$.

Table.1 Physicochemical and functional properties of adult male mithun (Bos frontalis) meat

\begin{tabular}{|l|l|}
\hline Meat quality parameters & Adult male \\
\hline Physicochemical characteristics & \\
\hline pH & $5.78 \pm 0.05$ \\
\hline Myoglobin (mg/g) & $5.19 \pm 0.14$ \\
\hline Salt soluble protein (\%) & $10.37 \pm 0.19$ \\
\hline Water Soluble protein (\%) & $6.86 \pm 0.39$ \\
\hline $\begin{array}{l}\text { Myofibrillar fragmentation index (MFI) } \\
(\%)\end{array}$ & $76.98 \pm 0.90$ \\
\hline Muscle fibre diameter ( $\boldsymbol{\mu m}) \#$ & $84.18 \pm 0.99$ \\
\hline Cooking loss (\%) & $34.62 \pm 0.99$ \\
\hline Moisture (\%) & $73.66 \pm 0.35$ \\
\hline Protein (\%) & $23.87 \pm 0.86$ \\
\hline Fat (\%) & $0.66 \pm 0.10$ \\
\hline Ash (\%) & $1.07 \pm 0.04$ \\
\hline Calorific value (kcal/100gm) & 104.38 \\
\hline Shear force (N) & $55.72 \pm 2.79$ \\
\hline Functional properties & \\
\hline Water holding capacity (ml/100g) & $31.38 \pm 1.67$ \\
\hline
\end{tabular}

Means with different superscripts in the same row indicate significant difference $(\mathrm{P}<0.05)$

Table.2 Sensory evaluation of cooked meat chunks from different group of mithun

\begin{tabular}{|l|l|}
\hline Sensory attributes & Adult male \\
\hline Appearance & $6.89 \pm 0.16$ \\
\hline Flavour & $7.44 \pm 0.54$ \\
\hline Juiciness & $7.28 \pm 0.09$ \\
\hline Tenderness & $6.53 \pm 0.15$ \\
\hline Connective tissue residue & $7.05 \pm 0.11$ \\
\hline Overall acceptability & $7.04 \pm 0.07$ \\
\hline
\end{tabular}

*Based on 8 point descriptive scale

Means with different superscripts in the same row indicate significant difference $(\mathrm{P}<0.05)$ 


\section{Calorific value}

Calorific value $(\mathrm{kcal} / 100 \mathrm{~g})$ was recorded to be 104.38. The calorific value $\mathrm{kcal} / 100 \mathrm{~g}$ of Cara beef and beef as reported by Naveena and Kiran (2014) is 173 and 99 respectively. Aziz et al., (2012) conducted comparative studies on nutritional quality of cattle and buffalo meat and reported that calorific values varied between two age group of buffalo below 2 years and above 2 years of age are 112.49 to $133.32 \mathrm{k}$ cal respectively and cattle calorific values varies between 117.2 to $125.15 \mathrm{k}$ cal below 2 years and above 2 years of age. Florek et al., (2017) reported the calorific value between 379 KJ (90.58 $\mathrm{kcal} / 100 \mathrm{gm})$ and $430 \mathrm{~kJ} \quad 100 \mathrm{~g}-1 \quad(102.77$ Kcal/100 gm) in beaver meat. Jankowska et al.(2005) reported that energy value of $510.3 \mathrm{~kJ} 100 \mathrm{~g}-1(121.96 \mathrm{Kcal} / 100 \mathrm{gm})$ for thigh522.2 kJ $100 \mathrm{~g}-1$ (124.81 Kcal/100gm) for loinfor sexually mature beaver meat.

\section{Shear force value}

Shear force and muscle fibre diameter are the two important parameter to reflect the tenderness of muscle, and are highly correlated. The Warner-Bratzler shear-force of adult male mithun meat was $55.72 \pm 2.79 \mathrm{~N}$. This was in agreement with the findings of Kiran et al., (2016) who reported WBSF old buffalo (above 10 years of age) meat as 54.28 $\mathrm{N}$.

\section{Water holding capacity}

Water Holding Capacity of mithun meat was recorded to be $31.38 \pm 1.67$. Li et al., (2018) reported a water holding capacity of $39.47 \pm 0.38$ of male Binlangjang buffalo meat (Longissimus thoracis) muscle of age 24-36 months. $\mathrm{pH}$ and water holding capacity of the meat is positively correlated. Previous authors (Huff-Lonergan and Lonergan, 2005; Ekiz et al., 2018) have indicated that low $\mathrm{pHu}$ might cause the development of low water holding capacity.Purchas (1990) indicated that greater the $\mathrm{pH}$, the greater water holding capacity.

\section{Sensory attributes}

Appearance, flavour, juiciness, tenderness, connective residue and overall acceptability scores of cooked meat chunks are presented in Table 2. Panelists gave lower scores for appearance, this could be due to the fact that meat becomes darker and redder with increase in age, which is mainly due to increase in concentration of myoglobin pigment with age (Lawrie, 1991). Panellist gave higher scores for juiciness in the present study because sustained juiciness increased with increased age and may be explained by the fact that more mastication would be required for samples from older animals (due to the increased cross-linking of the collagen with increased age) and, therefore, more saliva would be released to increase the perceived sustained juiciness.

This corresponds with the conclusions of Huff and Parrish (1993) that carcasses of young $\leq$ carcasses of older animals ( $C$ to $E$ maturity) were juicier than bulls and steers (A maturity). Juiciness in their study was described as an estimation of the amount of free fluids released by chewing and it was, therefore, comparable to sustained juiciness in this study. Lower scores for juiciness were obtained as meat becomes tougher with age. Tenderness scores were lower and connective tissue residues scores were higher in the present study.

This could be due to the higher amount of connective tissue in older animals resulted in decreased tenderness in meat (Huff et al., 1993).Reagan et al., (1976) reported that meat from younger age group were found to be significantly $(\mathrm{P}<0.05)$ more tender than older animals 


\section{Acknowledgement}

The authors would like to acknowledge ICAR-NRC on mithun Medziphema, Dimapur, Nagaland for providing necessary financial and infrastructural facilities in conducting the study.

\section{References}

Anjaneyulu, A.S.R., Sengar, S.S., Lakshmanan, V. and Joshi, B.C. 1985. Meat quality omale buffalo calves maintained in different levels of protein. Buffalo Bulletin, 4: 44-47.

Anjaneyulu, A.S.R., Sharma, N., Kondaiah, N. 1989. Evaluation of salt, polyphosphates and their blends at different levels on physicochemical properties of buffalo meat and patties. Meat Science, 25(4): 293-306.

AOAC. 2016. Official Methods of Analysis. Association of Official Analytical Chemists, 20 ${ }^{\text {th }}$ Ed.925.10. Editor- Dr George W. Latimer, Jr. Published by AOAC international suite 300, 2275 Research BLVD Rockville, Maryland 20850-3250, USA.

Aziz, A., Shah, A.H., Haq, I.I., Khaskheli, M., Salman, M., Talpur, A.R. 2012. Comparative studies on nutritional quality of cattle and buffalo meat. International Journal of Science and Research, 3(7): 524-531.

Babji, A.S., Ooi, P.H. and Abdullah, A. 1989. Determination of Meat Content in Processed Meats Using Currently Available Method. Pertanika, 12(1): 33-41.

Davis, G.W., Dutson, T.R., Smith, G.C. and Carpenter, Z.L. 1980. Fragmentation procedure for bovine longissimus muscle as an index of cooked steak tenderness. Journal of Food Science, 45: 880-885.

Ekiz, B., Yilmaz,A., Yalcintan, H., Yakan,A.,
Yilmaz, I., Soysa, I. 2018. Carcass and meat quality of male and female water buffaloes finished under an intensive production system. Annals of Animal Science, 18 (2): 557-574.

Froning, G.W., Daddarid, J. and Hartung, T.E. 1968. Color and myoglobin concentration in turkey meats as effected by age, sex, and strain. Poultry Science, 47: 1827-1836.

Garnier, J., Klont, R. and Plastow, G. 2003. The potential impact of current animal research on the meat industry and consumer attitude towards meat. Meat Science, 63: 79-88.

Gupta, S.C., Gupta, N., Nivsarkar, A.E.1999. Mithun - a bovine of Indian origin, vol. 85Directorate of Information and Publication on Agriculture. ICAR, New Delhi, India, pp. 124.

Heli, T, Saikia S and Bora, N. N. 1994. Carcass characteristics of Mithun under different age group. Indian Journal of Animal Production and Management 10: 5-11.

Honikel KO. 1998. Reference methods for the assessment of physical characteristics of meat. Meat Sci 49:447-457.

Huff, E.J. and Parrish, F.C. 1993. Bovine longissimus muscle tenderness as affected by post mortem aging time, animal age and sex. Journal of Food Science, 58(4): 713-716.

Huff, E.J. and Parrish, F.C. 1993. Bovine longissimus muscle tenderness as affected by post mortem aging time, animal age and sex. Journal of Food Science, 58(4): 713-716.

Huff-Lonergan, E. and S. M. Lonergan. 2005. Mechanisms of water holding capacity of meat: The role of postmortem biochemical and structural changes. Meat Science, 71: 194-204.

Ilavarasan, R., Robinson, J.J., Abraham, V. Appa Rao, V., Ruban, S.W. and Ramani, R. 2016. Effect of afe on 
meat quality characteristics and nutritional composition of Toda buffalo. Buffalo bulletin, 35(2):215223.

Jankowska, B., Zmijewski, T., Kwiatkowska, a., Korzeniowski, W. 2005. The composition and properties of beaver (Castor fiber). European Journal of Wildlife Research. 51: 283-286.

Jeremiah, L.E., and Martin, A.H. 1982. Effect of pre rigor chilling and freezing and subcutaneous fat cover upon the histological and shear properties of bovine longissimus dorsi muscle. Journal of Animal Science, 62: 353361.

Kandeepan, G., Anjaneyulu, A.S.R., Kondaiah, N., Mendiratta, S.K. and Lakshmanan, V. 2009a. Effect of age and gender on the processing characteristics of buffalo meat. Meat Science, 83(1):10-14.

Keeton, J.T., 1983. Effects of fat and $\mathrm{NaCl} /$ phosphate levels on the chemical and sensory properties of pork patties. Journal of Food Science, 48: 878-881,885.

Kesava Rao, V., and Kowale, B.N.1991. Changes in phospholipids of buffalo meat during processing and storage. Meat Science. 30:115-129.

Kiran, M., Naveena, B., M., Reddy, K.S., Shashikumar, M., Reddy, V.R., Kulkarni, V.V., Rapole, S. and More, T.H. 2016. Understanding tenderness variability and ageing changes in buffalo meat: biochemical, ultrastructural and proteome characterization. Animal, 10:6, 10071015.

Kiran, M., Naveena, B. M., Reddy, K.S., Shashikumar, M., Reddy, V.R., Kulkarni, V.V., Rapole, S. and More, T.H.2015. Muscle-specific variation in buffalo (Bubalus Bubalis) meat texture: biochemical, ultrastructural and proteome characterization. Journal of Texture Studies 46: 254-261 ISSN 1745-4603.

Knipe, C.L., Olson, D.G. and Rust, R.E.1985. Effects of selected inorganic phosphates, phosphate levels and reduced chloride levels on protein solubility, stability and $\mathrm{pH}$ of meat emulsions. Journal of Food Science, 50: 1010 .

Kondaiah, N., Anjaneyulu, A.S.R., Rao, K.V. and Sharma, N. 1986. Effect of different handling conditions on quality of minced buffalo meat. Indian Journal of Animal Sciences, 56(6): 677-679.

Kulkarni, V.V., Kowale, B.N., Kesava Rao, V. and Murthy, T.R.K. 1993. Storage stability and sensory quality of washed ground buffalo meat and meat patties during refrigerated storage. Journal of Food Science and Technology, India, 30(3): 169-171.

Lapitan, R.M., Barrio, A.N.D., Katsubeo, Tokuda, T.B., Orden, E.A., Robles, A.Y., Cruz, L.C., Kanai, Y., Fujihara, T. 2008. Comparison of carcass and meat characteristics of Brahman grade cattle (Bos indicus) and crossbred water buffalo (Bubalus bubalis) fed on high roughage diet. Animal Science Journal, 79:210-217.

Lawrie, R.A., 1991. Meat Science, 5th edn. Oxford: Pergamon Press

Li, Q., Wang, Y., Tan, L., Leng, J., Lu, Q., Tian, S., Shao, S., Duan, C., L, W. Mao, H. 2018. Effects of age on slaughter performance and meat quality of Binlangjang male buffalo. Saudi Journal of Biological Sciences, 25:248-252.

Mahajan, S., Papang, J.S., Datta, K.K. 2015. Meat consumption in North East India: Pattern, Opportunities and Implication. Journal of Animal Research, Pp. 37-45. 
Mondal, S.K., Bujarbaruah, K. M., Khate, K.and Borah, I. P.2004a. Body conformation traits in mithun (Bosfrontalis). Indian Journal of Animal Sciences 74 (1): 84-87.

Mondal, S.K., Pal, D.T. and Bujarbaruah, K. M.2004. Growth rate and biometrical measurements in mithun calves under semi-intensive system. Indian Journal of Animal Sciences 74 (1): 66-68.

National Health and Medical Research council, 2006. Nutrient reference values for Australia and New Zealand, Department of Health and Ageing.

Naveena, B.M., Kiran, M., Reddy, S. K., Ramakrishna, C., Vaithiyanathan, S., Devatkal, S.K. 2011. Effect of ammonium hydroxide on ultrastructure and tenderness of buffalo meat. Meat Science, 88(4): 727-732.

Naveena, B.M., Mendiratta, S.K. and Anjaneyulu, A.S.R. 2004. Tenderization of buffalo meat using plant protease from Cucumis trigonusroxb (Kachri) and Zinziber officinale roscoe (Ginger rhizome). Meat Science, 68(3): 363-369.

Nishida, J., and Nishida, T. 1985. Relationship between the concentración of myoglobin and parvalbumin in various types of muscle tissue from chickens. British Poultry Science, 26:105-115.

Nuraina, H., Mahmudaha, A., Winartob, Sumantri, C. 2013. Histomorphology and physical characteristics of buffalo meat at different sex and age. Media Peternakan, 4:11-13.

Purchas, R.W.,1990. An assessment of the role of $\mathrm{pH}$ differences in determining the relative tenderness of meat from bulls and steers. Meat Science, 27: $120-140$

Rajkhowa, C., 2005. Genetic improvement of mithun (Bos frontalis) in India- An evaluation and future breeding policy. VIII $^{\text {th }}$ National conference on Animal Genetics and Breeding. $8-10^{\text {th }}$ March, pp 143-148.

Rao, V.A., Thulasi, G., Ruban, S. W and Thangaraju, P. 2009. Optimum age of slaughter of non-descript buffalo: Carcass and yield characteristics. Thai Journal of Agricultural Science, 42(3): 133-138.

Reagen, J.O., Carpenter, Z.L. and Smith, G.C.1976. Age-related traits affecting the tenderness of the bovine longissimus muscle. Journal of Animal Science. 43: 1198.

Seideman, S.C., Koohmaraie, M. and crouse, J.D. 1987. Factors associated with tenderness in young beef. Meat Science, 20: 281-291.

Shrikhande, G. B., Koltc, A. Y. and Koltc, B. R. 1996. Phenotypic characters or Nagpuri (Berari) buffaloes. Indian Veterinary Journal. 73: 1198-99.

Trout, S.E., Hunt, M.C., Johnson, D.E., Clauss, J.R., Kastner, C.L., Kropf, D.H. and Stroda, S.1992. Chemical, physical and sensory characterization of ground beef containing $5 \quad-10$ percent fat. Journal of Food Science, 57(1): 25-29.

Valin, C., Pinkas, A., Dragner, H., Boikovski, S. and Polikronov, D.1984. Comparative study of buffalo meat and beef. Meat Science, 10: 69-84.

Wardlaw, F.B., Maccaskill, L.H. and Acton, J.C. 1973. Effect of postmortem muscle changes in poultry meat loaf properties. Journal of Food Science, 38:421-424.

Warris, P.D., 1979. The extraction of haem pigments from fresh meat. Journal of food Technology, 14: 75-80.

Warris, P.D., 2000. Meat science: an introductory text. CAB international, CABI Publishing, Wallingford, UK.pp $23,25-27,42 \& 56$. 
Watts, G.F., Ahmed, W., Houlston, Q.J.R., Jackson P., Iles, C. and Lewis, B. 1988. Effective lipid lowering diets including lean meat. British Medical Journal (Clinical Research Edition), 297: 235-237.

Zarasvand, S.A., Kadivar, M., Mahmoud
Aminlari and Shahram S. Shekarforoush. 2012. A comparative study of physico-chemical and functional properties, and ultrastructure of ostrich meat and beef during aging. CyTA - Journal of Food. 10 (3) 201-209.

\section{How to cite this article:}

Lalchamliani, Geeta Chauhan, Abhijit Mitra, S.S. Hanah and Chamuah, J.K. 2019. Quality Evaluation of Meat from Adult Male Mithun (Bos frontalis). Int.J.Curr.Microbiol.App.Sci. 8(05): 137-149. doi: https://doi.org/10.20546/ijcmas.2019.805.018 